\title{
Histological analysis of arteriovenous anastomosis-like vessels established in the corpus luteum of cows during luteolysis
}

\author{
Junko Nio-Kobayashi ${ }^{1 *}$, Kaya Miyazaki ${ }^{1}$, Kazuhisa Hashiba², Kiyoshi Okuda ${ }^{2,3}$ and Toshihiko Iwanaga'
}

\begin{abstract}
Background: The mechanisms regulating the function and regression of the corpus luteum (CL) have not yet been elucidated in detail. The regressed $\mathrm{CL}$ of cows was previously reported to be filled with unusual vessels like arteriovenous anastomosis (AVA); however how these vessels are being established during luteolysis remains unknown.

Methods: The bovine $\mathrm{CL}$ at different luteal stages and regressing bovine $\mathrm{CL}$ induced by prostaglandin $\mathrm{F}_{2 a}$ (PGF) were histologically analyzed using light and electron microscopic levels. The changes in mRNA expression of genes encoding a-smooth muscle actin (SMA; Acta2) and transforming growth factor $\beta 1$ (Tgfb1) in luteal tissues were analyzed by quantitative RT-PCR.

Results: AVA-like vessels appeared in the regressed $C L$ with a diameter less than $1.5 \mathrm{~cm}$ in which no functional luteal cells and macrophages were observed. Epithelioid cells in the AVA-like vessel wall were immunoreactive for SMA, and the lumen of the vessels were narrow. Immunoreaction for SMA was found in the tunica media of typical arteries and arterioles, and pericytes around capillary vessel. Cells with elongated cytoplasmic processes - resident fibroblasts expressing vimentin - distributed in the $\mathrm{CL}$ parenchyma without any association with blood vessels are also immunoreactive for SMA, and accumulated around arteries and arterioles during the lateluteal stage. In the regressed $\mathrm{CL}$, walls of arteries and arterioles consisted of more than two layers of epithelioid cells positive for both SMA and desmin, suggesting that they are myofibroblasts transformed from fibroblasts. The percentage of the area positive for SMA and the mRNA expression of Acta2 were significantly increased in the regressed $\mathrm{CL}$; however, they did not alter when a luteolytic dose of PGF was injected in vivo and collected within $24 \mathrm{~h}$ after the injection. On the other hand, Tgfb1, a known regulator for myofibroblast transformation, was significantly increased in PGF-induced regressing $\mathrm{CL}$ as well as in the $\mathrm{CL}$ during the late-luteal stage.

Conclusions: SMA-positive myofibroblasts accumulates around the arteries and arterioles to form AVA-like vessels during luteolysis in cows. PGF indirectly regulates myofibroblast transformation through enhancing the expression of TGF $\beta 1$. These peculiar AVA-like vessels may be involved in the regulation of blood flow in the bovine $\mathrm{CL}$ during luteolysis.
\end{abstract}

Keywords: Luteolysis, Arteriovenous anastomosis, Myofibroblasts, PGF $2 a$, TGF 1

\footnotetext{
* Correspondence: niojun@med.hokudai.ac.jp

'Laboratory of Histology and Cytology, Hokkaido University Graduate School

of Medicine, Kita 15-Nishi 7, Kita-ku, Sapporo 060-8638, Japan

Full list of author information is available at the end of the article
} 


\section{Background}

The corpus luteum (CL) is formed from an ovulated dominant follicle in the ovary, and secretes progesterone, which is essential for the establishment and maintenance of pregnancy. In mammals, the CL undergoes luteolysis at the end of luteal phase [1]. There are two phases in luteolysis: functional and structural luteolysis. Functional luteolysis is characterized by a decrease in serum progesterone concentrations and is followed by structural luteolysis, in which the volume of the $\mathrm{CL}$ decreases due to apoptotic death of luteal cells. It is generally accepted that spontaneous luteolysis in cows is initiated by uterus-derived prostaglandin $\mathrm{F}_{2 \alpha}$ (PGF) if pregnancy does not occur [2]. In cows, serum concentration of progesterone markedly decreases approximately 19 days after ovulation and this is accompanied by an increase in plasma PGF metabolites, which represents the production of PGF in the uterus [3]. An intramuscular injection of PGF into cows during the mid-luteal stage - but not the early-luteal stage - has been shown to induce luteolysis, resulting in a rapid decrease in serum progesterone levels eight hours after the injection [3, 4]. Although PGF is a major luteolysin in cows, the molecular mechanisms by which PGF regulates functional and structural luteolysis currently remain unclear; however, its effects are known to be mediated by various intra-ovarian factors, such as endothelin 1, nitric oxide, angiotensin II, and interferon $\gamma[5-11]$.

In cows, ovarian blood flow decreases during luteal regression $[4,12]$ and the resulting hypoxic condition affects functional and structural luteolysis [13] although a temporal increase in blood flow has been reported in spontaneous and PGF-induced luteolysis [3]. Previous studies noted morphological changes in the vasculature during luteolysis in ewes [14] and cows [15]. Sawyer et al. [14] found that vascular occlusion occurred following the sloughing of endothelial cells into the lumina of small blood vessels during luteolysis, suggesting that vascular occlusion causes a decreased blood supply, resulting in hypoxic conditions in the CL. Hojo et al. [15] demonstrated that capillaries disappeared within the CL at the late and regressed luteal stages, whereas larger blood vessels that stained for $\alpha$-smooth muscle actin (SMA) increased in number. Changes in the vascular structure have been suggested to contribute to a decrease in blood flow and luteolytic process in the CL.

Although remodeling of the vasculature in the CL appears to be essential in the regulation of luteal function during luteolysis, the mechanisms responsible for controlling changes in vascular structures in the bovine CL during luteolysis have yet to be clarified. Höflinger [16] noted the existence of arteriovenous anastomosis (AVA)-like vessels in the regressed CL of cows. AVA is characterized by precapillary connections between small arteries and veins. AVA called Hoyer-Grosser's organs are distributed in the subcutaneous tissue of the tips of the fingers and toes of humans, and have also been reported in the ears of some animals including rabbits. The corpora cavernosa penis of various animals possesses a similar structure in the helicine arteries [17-19]. AVA is a vascular shunt and is involved in the regulation of blood flow in the skin or corpora cavernosa penis. Without stimulations by vasodilative molecules such as nitric oxide secreted from peripheral nerves, AVA contracts and blood flow is remarkably obstructed. AVA shows a characteristic morphology that is markedly different from those of normal arteries and veins: unique round epithelioid cells form the walls of AVA. Epithelioid cells are contractive cells containing SMA in the cytoplasm, and react to both vasoconstrictive and vasodilative signals such as endothelin and nitric oxide [20].

Because the blood flow is known to decrease during luteolysis and the appearance of AVA-like vessels is likely to contribute to a decrease in blood flow in the CL of cows during luteolysis; however, the role of AVA-like vessels in regulating the function of $\mathrm{CL}$ and how this structure is constructed in the $\mathrm{CL}$ remain unclear. The objective of this study is to clarify the contribution of AVA-like vessels to the regulation of luteal function in cows, we herein investigated how they are formed in the bovine $\mathrm{CL}$ during luteolysis using histological techniques.

\section{Methods}

\section{Tissue collection}

Ovaries with the $\mathrm{CL}$ of Holstein cows were obtained at a local abattoir, kept in normal saline at $25-30{ }^{\circ} \mathrm{C}$, and delivered to the laboratory within $6 \mathrm{~h}$ of being collected. Luteal stages were classified as early-luteal (days 2-3 after ovulation), mid-luteal (days 8-12), late-luteal (days 15-17), and regressed (over day 19) by macroscopic observations of the CL according to a previous study [21]. The stages of the bovine CL were classified into the early-luteal $(n=7)$, mid-luteal $(n=13)$, late-luteal $(n=14)$, and the regressed stages $(n=31)$. Collection of the CL tissues was approved by the local ethical committee of Hokkaido University (Approval no. 13-0052).

The animal procedures used to collect PGF-induced regressing $\mathrm{CL}$ tissues were approved by the local Institutional Animal Care and Use Committee of the Polish Academy of Science in Olszyn, Poland (Agreement No. 5/2007, 6/2007 and 88/2007). Healthy, normally cycling Polish Holstein black and white cows were used for the collection of PGF-induced regressing CLs. Estrus was synchronized in cows by two injections of an analogue PGF (25 mg; Dinoprost, Dinolytic; Pharmacia and Upjohn, Puurs, Belgium) with an 11-day interval according to the manufacturer's instructions. Ovaries were 
collected $0,2,12$, and $24 \mathrm{~h}$ after the injection of a luteolytic dose of the PGF analogue $(25 \mathrm{mg})$ on postovulation day 10 using a Hauptner's effeninator (Hauptner \& Herberholz, Solingen, Germany). Total 25 PGF-treated CL and control mid-luteal CL were used in this study, and detailed information of the tissues is summarized in Table 1.

CL tissues dissected out from the ovaries were halved, and either immersed in fixatives as described below for the histological analysis or frozen in liquid nitrogen for RNA purification. Information on the CL used for this study was summarized in Table 1.

\section{Histological analysis}

CL tissues were dissected from the ovaries and immersed in $4 \%$ paraformaldehyde for $24 \mathrm{~h}$ at $4{ }^{\circ} \mathrm{C}$. Tissues were dehydrated through graded series of ethanol and immersed into xylene, then embedded in paraffin according to the standard methodology, and 5- $\mu \mathrm{m}$-thick sections were obtained. Sections were de-waxed, subjected to Hematoxylin and Eosin staining, and observed under a light microscope (BX51; Olympus corporation, Tokyo, Japan). The middle CL parenchyma tissues were dissected into small pieces and fixed with $2.5 \%$ glutaraldehyde for ultrastructural observations under a transmission electron microscope (TEM, H-7100; Hitachi, Tokyo, Japan). Tissue pieces were post-fixed with $1 \%$ OsO4 for $1.5 \mathrm{~h}$, dehydrated through a graded series of ethanol, and embedded into Epon resin (Quetol 812). Ultra-thin sections were obtained, stained with uranyl acetate lead citrate, and observed under a TEM.

\section{Immunohistochemistry}

All procedures were performed at room temperature. After deparaffinization, endogenous peroxidase was blocked by $3 \% \mathrm{H}_{2} \mathrm{O}_{2}$ in distilled water for $20 \mathrm{~min}$.
Sections were then incubated with Avidin/Biotin blocking solution (Vector Laboratories Inc., Burlingame, CA, USA) for $15 \mathrm{~min}$ each. After washing with phosphatebuffered saline (PBS) twice, sections were pre-incubated for non-immune blocking with Block Ace (DS Pharma Biomedical Co., Ltd., Osaka, Japan) for $60 \mathrm{~min}$. Sections were then incubated with a mouse anti-SMA antibody (1:1,000; clone 1A4, \#A2574; Sigma-Aldrich Corporation, St. Louis, MO, USA) in PBS overnight. The sections were incubated with biotinylated anti-mouse IgG (1:500; Vector Laboratories Inc.) for $1 \mathrm{~h}$, followed by an incubation using a Vectastain ABC Elite kit (Vector Laboratories Inc.) for $1 \mathrm{~h}$. The reaction site of the primary antibody was visualized using an ImmPACT ${ }^{\mathrm{TM}}$ DAB Peroxidase Substrate Kit (Vector Laboratories Inc.) for $3 \mathrm{~min}$. Sections were counterstained with hematoxylin and observed under a light microscope. The total CL area in the section and the SMA-immunoreactive area in the CL were measured using Image J (http://imagej.nih.gov/ij/), and the percentage of SMA-positive area per the total CL area was calculated. Control sections were incubated with PBS instead of the primary antibody and the disappearance of the signals was confirmed.

For luteal steroidogenic cell, macrophage, and proliferating cell staining, antigen retrieval was performed for $1 \mathrm{~min}$ in boiling $0.01 \mathrm{M}$ citrate buffer ( $\mathrm{pH}$ 6.0) using a pressure cooker. Endogenous peroxidase and Avidin/ Biotin blocking were then performed as described above. After a pre-incubation with Block Ace for $1 \mathrm{~h}$, the sections were incubated with either goat anti-3 $\beta$-hydroxysteroid

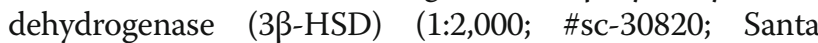
Cruz Biotechnology, Inc., Dallas, TX, USA), mouse anti-MAC387 (1:1,000; \#ab22506; Abcam Japan Ltd., Tokyo, Japan), which recognizes the L1 or Calprotectin molecule, an intracytoplasmic antigen expressed by tissue macrophages, or rabbit anti-Ki-67 antibody (1:200;

Table 1 Information on the bovine corpus luteum used for the present study

A: Normal cycling CL

$$
\text { Luteal stages }
$$

\begin{tabular}{|c|c|c|c|c|c|}
\hline & & EL & $M L$ & $\mathrm{LL}$ & Reg \\
\hline \multirow[t]{2}{*}{ Number of samples } & For the histological analysis & 7 & 13 & 14 & 31 \\
\hline & For the $\mathrm{qPCR}$ analysis & 4 & 4 & 5 & 7 \\
\hline Days after ovulation & & $2-3$ & $8-12$ & $15-17$ & $>19$ \\
\hline Color & & Flesh, Bloody & Orange & Yellow & Ocher, Brown, White \\
\hline Size (cm) & & $1.9 \pm 0.19$ & $2.5 \pm 0.07$ & $2.1 \pm 0.14$ & $0.9 \pm 0.06$ \\
\hline
\end{tabular}

B: PGF-induced regressing $C L$

Hours after the PGF injection

Number of samples $\quad$ For the histological analysis For the qPCR analysis
0

$4 \quad 10$

5

\section{0}

6

EL early-luteal, $M L$ mid-luteal, LL late-luteal, Reg regressed 
ThermoFisher Scientific Inc., Waltham, MA, USA) overnight. Sections incubated with the $3 \beta-$ HSD antibody were then incubated with a peroxidase-labeled anti-goat IgG (1:200; Vector Laboratories Inc.) for $1 \mathrm{~h}$. On the other hand, MAC387- and Ki-67-stained sections were incubated with biotinylated anti-mouse or rabbit IgG for $1 \mathrm{~h}$ and Vecterstain ABC Elite kit as described above. Reaction sites for all three antibodies were visualized using an ImmPACT $^{\text {тм }}$ DAB Peroxidase Substrate Kit (Vector Laboratories Inc.) for $3 \mathrm{~min}$ and observed under a light microscope as described above. The total CL area in the section and the number of $3 \beta-H S D$ - or MAC387-immunoreactive cells in the CL was measured using Image J, and the positive cell number in $1 \mathrm{~mm}^{2}$ was calculated.

For double immunostaining for SMA and Ki-67, the deparafinized sections were rinsed in distilled water and antigen retrieval was performed by boiling the sections in $0.01 \mathrm{M}$ citrate buffer ( $\mathrm{pH}$ 6.0) for 1 min using a pressure cocker. The sections were incubated with Block Ace for $1 \mathrm{~h}$ and rabbit anti-Ki-67 antibody overnight as described above. After washing with PBS three times, the sections were incubated with Alexa Fluor 488conjugated anti-rabbit IgG (1:200; Life Technologies Japan, Tokyo, Japan) for 2 h. The sections were again incubated with Block Ace for $1 \mathrm{~h}$ and then incubated with mouse anti-SMA antibody as described above. The binding site for SMA antibody was visualized using AlexaFluor 594-labeled anti-mouse IgG (1:200; Life Technologies Japan) and observed under a confocal laser microscope (FV300; Olympus, Tokyo, Japan).

For triple staining, sections were incubated with a mouse anti-vimentin antibody (1:500; Dako Japan ltd., Tokyo, Japan) overnight, and then with biotinylated anti-mouse IgG for $1 \mathrm{~h}$ as described above. The antibody-binding site for the $1^{\text {st }}$ primary antibody against vimentin visualized using the TSA $^{\mathrm{TM}}$ Fluorescein System (PerkinElmer Inc., Waltham, MA, USA). The $1^{\text {st }}$ primary antibody was washed out in boiling $0.01 \mathrm{M}$ citrate buffer ( $\mathrm{pH}$ 6.0) using a microwave for $2.5 \mathrm{~min}$, and sections were then blocked with Block Ace for $1 \mathrm{~h}$. They were incubated with the $2^{\text {nd }}$ primary antibody, a rabbit anti-desmin antibody (1:500; ThermoFisher Scientific Inc.) overnight and with a Cy5-labeled anti-rabbit antibody (1:200; Jackson ImmunoResearch Laboratories, Inc., West Grove, PA, USA) for $2 \mathrm{~h}$. Sections were again blocked with Block Ace for $60 \mathrm{~min}$ and then incubated with a $3^{\text {rd }}$ primary antibody, the mouse anti-SMA antibody (1:500). The binding site for the $3^{\text {rd }}$ primary antibody was visualized by AlexaFluor 594-labeled anti-mouse IgG (1:200; Life Technologies Japan). Sections were observed under a confocal laser microscope as described above. Lasers used in this study were $\operatorname{Ar}(488 \mathrm{~nm}), \mathrm{HeNe}(\mathrm{G})$ (543 nm), and HeNe (R) (633 nm).

\section{Quantitative PCR (qPCR)}

Total RNA from bovine CL tissues during the earlyluteal $(n=4)$, mid-luteal $(n=4)$, late-luteal $(n=5)$, and regressed stages $(n=7)$ was purified using Trizol $^{\circ}$ (Thermo Fisher Scientific) according to the manufacturer's instructions. Two hundred nanograms of total RNA were used to prepare cDNA using a QuantiTect Reverse Transcription kit (Qiagen Japan Co. Ltd., Tokyo, Japan). QPCR was performed using a KAPA SYBR First qPCR kit (Nippon Genetics Co., Ltd., Tokyo Japan) according to the manufacturer's instructions. The sequences of the primer sets used for this study are listed in Table 2. Primers were pre-validated by standard PCR and by generating standard curves using qPCR. The qPCR cycling program consisted of a denaturing step $\left(95{ }^{\circ} \mathrm{C}\right.$ for $3 \mathrm{~min}$ ), annealing and extension step ( $95{ }^{\circ} \mathrm{C}$ for $3 \mathrm{~s}$ and $60{ }^{\circ} \mathrm{C}$ for $20 \mathrm{~s}$ repeated for 40 cycles), and a dissociation step (ramp from 60 to $95{ }^{\circ} \mathrm{C}$ ) using Corbett Rotor-gene 6000 (Qiagen Japan Co, Ltd.). The relative expression levels of each target to the housekeeping gene (glyceraldehyde 3-phosphate dehydrogenase: Gapdh) were quantified using the ${ }^{\Delta} \mathrm{Ct}$ method.

\section{Statistical analysis}

After testing for normality, all statistical analyses were performed using one-way ANOVA with Tukey's multiple comparisons test using GraphPad Prism 6 software (GraphPad Software Inc., San Diego, CA, USA), and $P<0.05$ was regarded as significant. Values in the graphs represent the mean \pm SEM.

\section{Results \\ Characteristic AVA-like vessels appear in the regressed CL of cows \\ Figure 1 shows macroscopic images of the equatorial plane of the bovine $\mathrm{CL}$ at each stage. The $\mathrm{CL}$ at the early-luteal stage displayed a flesh or bloody color and was very soft (Fig. 1a). The CL during the mid-luteal and late-luteal stages was large with a diameter of more than}

Table 2 Primers used for the present study

\begin{tabular}{lllll}
\hline Gene name & Accession no. & Forward & Reverse & Product size \\
\hline Gapdh & BC102589 & caccctcaagattgtcagca & ggtcataagtccctccacga & 103 \\
Acta2 & NM_001034502 & gccgagatctcaccgactac & gtgatcacctgcccatcag & 202 \\
Tgfb1 & NM_001166068 & ccttcctgctcctcatgg & ggttgtgctggttgtacagg & 276 \\
\hline
\end{tabular}



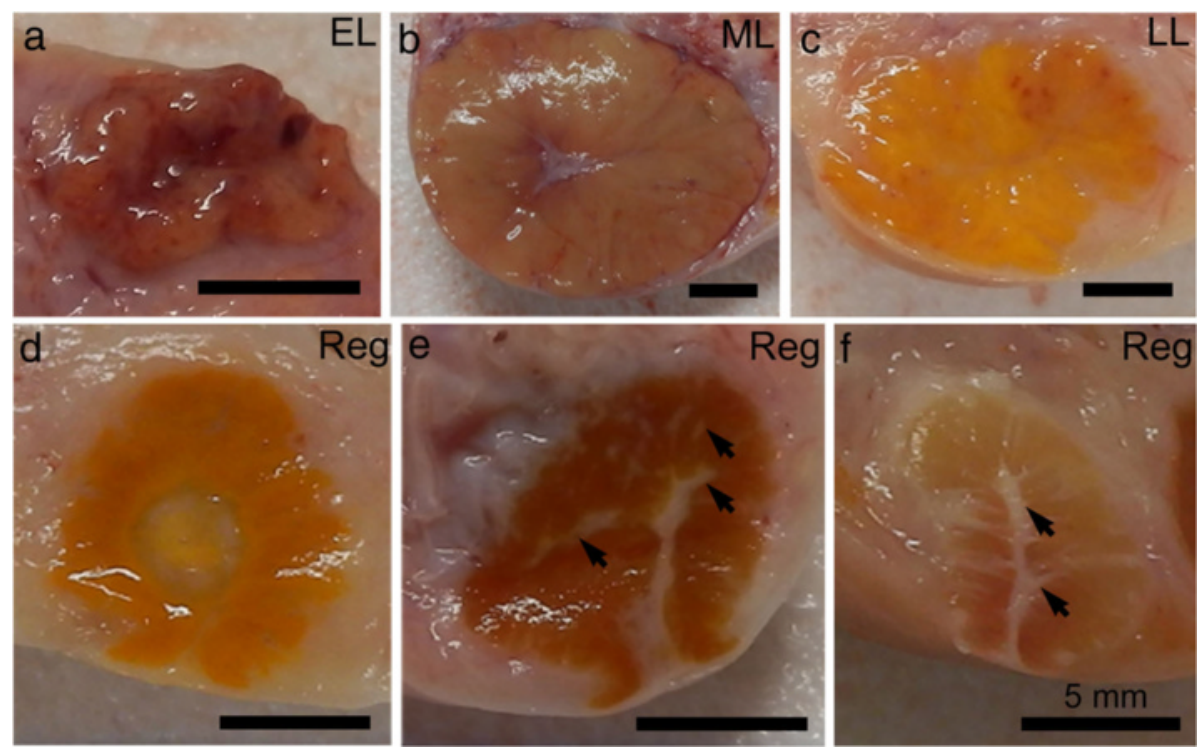

Fig. 1 Macroanatomical images of the bovine CL. The CL was cut through an equatorial plane. The color of the CL during the early-luteal (EL) stage is bloody or flesh and size was less than $2.0 \mathrm{~cm}(\mathbf{a})$. The $\mathrm{CL}$ during the mid-luteal (ML) and late-luteal (LL) stages increased in size to more than $2.0 \mathrm{~cm}$ in diameter $(\mathbf{b}, \mathbf{c})$. The color of the $\mathrm{CL}$ during the $\mathrm{ML}$ stage is flesh or orange (b), while that during the $\mathrm{LL}$ stage turns to yellow (c). Regressed CLs are small with a diameter of less than $1.5 \mathrm{~cm}$ and show various colors such as ocher (d), brown (e), or white (f). Arrows in E and F show connective tissue in the $\mathrm{CL}$ parenchyma

$2.0 \mathrm{~cm}$ (Fig. 1b, c). The color of the CL at the mid-luteal stage was flesh or orange while that at the late-luteal stage was yellow (Fig. 1b, c). The regressed CL with a diameter less than $1.5 \mathrm{~cm}$ showed various colors, such as ocher, brown, or white (Fig. 1d-f). The color of the regressed $\mathrm{CL}$ occasionally resembled that of the $\mathrm{CL}$ at the early-luteal phase, while the regressed CL was harder and possessed septa of connective tissue in the CL parenchyma (arrows in Fig. 1e, f).

Under a light microscope, the parenchyma of the regressed CL was filled with characteristic vessels possessing thick walls (Fig. 2a). Large arteries with an external diameter of more than $200 \mu \mathrm{m}$ possessed a thick tunica media and were located at the periphery of the CL (arrows in Fig. 2a). The CL parenchyma contained numerous and condensed arteries of various sizes (Fig. 2a, b). Vessels with a diameter of 100-200 $\mu \mathrm{m}$, possibly modified small arteries, possessed more than four layers of SMA-positive epithelioid cells in their walls and a narrow lumen, possessing the features of typical AVA (asterisks in Fig. 2a, b). Observations of AVA-like vessels under an electron microscope clearly showed the characteristic structure of the vessels with a similar morphology to that of AVA, particularly in the small arteries (Fig. 2c). The walls of AVA-like vessels in the regressed CL consisted of round epithelioid cells, each of which possessed a basement membrane similar to smooth muscle cells (asterisks in Fig. 2c). The lumens of the meandering small-sized vessels were narrow, suggesting their contractive condition (Fig. 2d, e).

\section{SMA-positive cells increase in number during luteolysis}

When the regressed bovine CL sections were immunostained for $\alpha$-smooth muscle actin (SMA), the wall of the vessels in the CL parenchyma were all immunolabeled. Thick tunica media of the large vessels at the periphery of the CL was immunoreactive for SMA, whereas the enlarged tunica intima of the larger arteries was not (arrow in Fig. 3a). The wall of AVA-like modified arteries was strongly immunoreactive for SMA (asterisks in Fig. 3a, b). Small-sized vessels, possibly derived from arterioles and capillaries, occupied the CL parenchyma and displayed a spiral running pattern and intense immunoreactivity for SMA in their walls (Fig. 3a, b).

Because the wall of AVA-like vessels was immunostained with SMA, we next investigated how AVA-like vessels formed during luteal regression by SMA immunohistochemistry. Tissue sections of the bovine CL throughout the luteal phases were immunostained for SMA and observed with special reference to changes in the vascular structure. During the early- and mid-luteal stages, SMA-immunoreactive arteries and arterioles of various sizes were dispersed in the CL; typical arteries were located in the connective tissues surrounding the $\mathrm{CL}$ and septa within the CL (asterisks in Fig. 3c), and arterioles were observed throughout the CL parenchyma (arrows in Fig. 3c, d). Immunoreactivity for SMA was largely restricted to the tunica media of the arteries (asterisks in Fig. 3c) and arterioles (arrows in Fig. 3c, d) as well as cytoplasm of pericytes surrounding capillary 


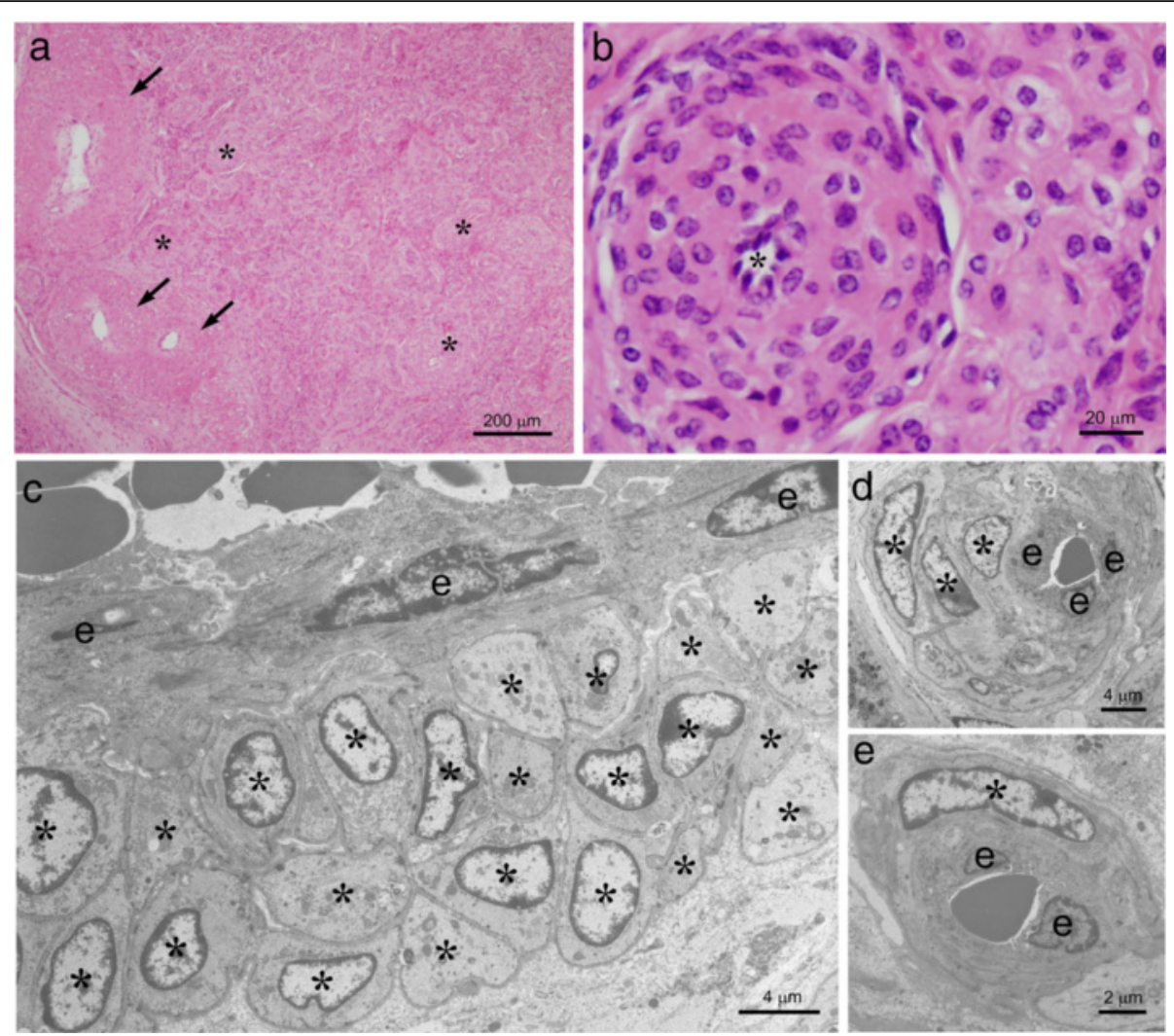

Fig. 2 Histological features of AVA-like vessels in the regressed $C L$ of cows. The regressed $C L$ of cows is filled with AVA-like vessels. Large vessels with an external diameter of more than $200 \mu \mathrm{m}$ are found in the periphery of the $\mathrm{CL}$ (arrows in a) and vessels of various sizes are distributed throughout the CL parenchyma (a). Vessels with a diameter of 100-200 $\mu \mathrm{m}$ resemble typical AVA possessing several layer of epithelioid cells in the walls and narrow lumens (asterisks in $\mathbf{a}, \mathbf{b}$ ). Ultrastructural observations under a TEM show how the epithelioid shape of cells in wall of an AVA-like vessel, each possessing a basement membrane similar to smooth muscle cells (asterisks in $\mathbf{c}$ ). The lumen of small-sized vessels is narrow, showing its contractive condition (d, e). e: endothelial cells

vessels (asterisks in Fig. 3d). Other cells extending thincytoplasmic processes between luteal steroidogenic cells but not being associated with blood vessels occasionally showed weak immunoreactivity for SMA (arrowhead in Fig. 3d). During the late-luteal phase, the intensity of the SMA immunoreaction increased in these stellate cells (Fig. 3e, f, h). Furthermore, abundant SMA-positive cells appeared to accumulate around the arteries and arterioles (asterisks in Fig. 3e, f). Pericytes were strongly immunoreactive for SMA and the network of the capillary vessels were visible in the $\mathrm{CL}$ at the late-luteal stage (asterisks in Fig. 3f, g). The percentage of the SMApositive area $(P<0.0001$, Fig. 4a) was significantly increased in the regressed CL in accordance with the elevated mRNA expression of Acta2 $(P<0.01$, Fig. 4b).

In order to elucidate the relationship between the appearance of AVA-like vessels and luteal function, we immunostained the sections with markers for a key enzyme in progesterone production $(3 \beta-\mathrm{HSD})$ or macrophages (MAC387), which increase in number during luteolysis [22]. Luteal steroidogenic cells during the mid- luteal stage expressed 3 3 -HSD in the cytoplasm (Fig. 5a), while MAC387-positive macrophages were sparse (Fig. 5b). During the late-luteal phase, the number of MAC387positive macrophages increased, whereas intact steroidogenic cells with the $3 \beta$-HSD immunoreaction was decreased (Fig. 5c, d). On the other hand, the number of $3 \beta$-HSD-positive intact luteal steroidogenic cells and MAC387-positive macrophages were both negligible in the regressed $\mathrm{CL}$ filled with SMA-positive AVA-like vessels (Fig. $5 \mathrm{e}, \mathrm{f}$ ). The number of $3 \beta$-HSD-positive steroidogenic cells was significantly low in the regressed $\mathrm{CL}$ $(P \leq 0.0001$; Fig. $5 \mathrm{~g})$, whereas MAC387-positive macrophages increased in number in the $\mathrm{CL}$ at the late-luteal stage ( $P \leq 0.05$; Fig. $5 \mathrm{~h})$. These results indicate that $\alpha$ SMApositive AVA-like vessels appear after the structural luteolysis.

\section{SMA-positive cells are myofibroblasts originating intraluteal fibroblast}

In order to investigate whether an increase in the number of SMA-positive stellate cells during luteolysis is due 

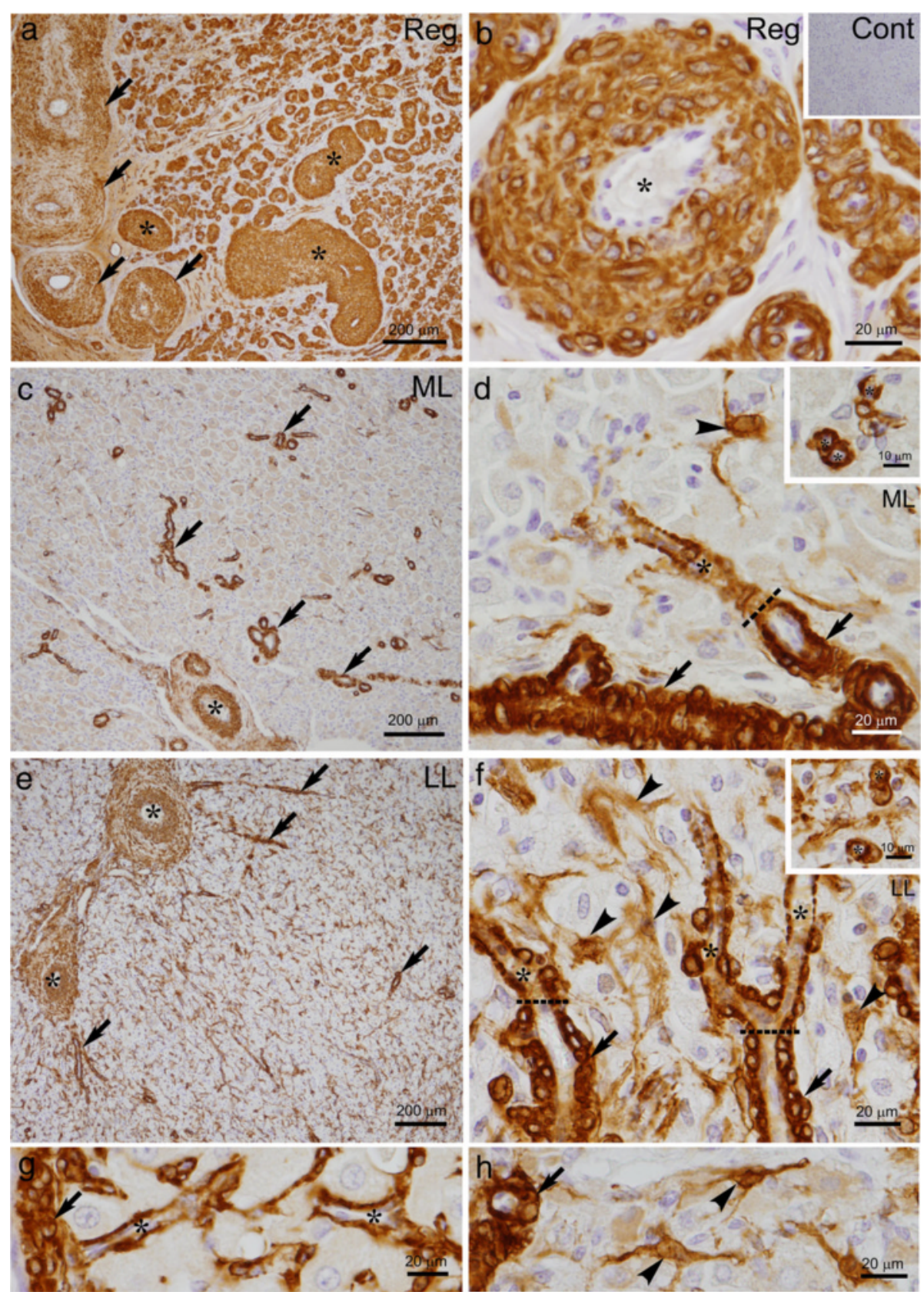

Fig. 3 Representative staining of SMA in the $C L$ during luteal stages. The walls of all vessels in the regressed (Reg) $C L$ exhibited strong immunoreactivity for SMA $(\mathbf{a}, \mathbf{b})$. Tunica media of the large vessels at the periphery of the CL contains SMA immunoreactivity (arrows in a). Cells in the wall of typical AVA-like vessels with a diameter of 100-200 $\mu \mathrm{m}$ are immunolabeled with SMA (asterisks in $\mathbf{a}$, $\mathbf{b}$ ). In the CL during the mid-luteal (ML) stages, the immunoreactivity for SMA is largely restricted to the tunica media of arteries and arterioles (asterisks in $\mathbf{c}$ and arrows in $\mathbf{c}$, $\mathbf{d}$ ). Pericytes surrounding capillary vessels also immunoreactive for SMA (asterisk in $\mathbf{d}$ ). Weak immunoreactivity for SMA is found in fibroblast-like cells lying between steroidogenic luteal cells but not being associated with blood vessels (arrowheads in d). During the late-luteal (LL) stage, abundant SMA-positive fibroblast-like cells are observed in the CL parenchyma and accumulate around the arteries (asterisks in $\mathbf{e}$ ). Smooth muscle cells in the arteries (asterisks in $\mathbf{e}$ ) and arterioles (arrows in $\mathbf{e}, \mathbf{f}$ ) as well as pericytes (asterisks in $\mathbf{f}$ ) are immunolabeled with SMA. Capillary vessel network is more visible in the CL at the LL stage (asterisks in $\mathbf{g}$ ). Fibroblastic cells with elongated cytoplasmic processes also contain SMA immunoreaction (arrowheads in $\mathbf{f}, \mathbf{h}$ ). Inserts in (d and $\mathbf{f}$ ) show traverse

images of capillary vessels. Dotted lines in ( $\mathbf{d}$ and $\mathbf{f}$ ) display changing points from arterioles to capillary vessels. Cont: negative control image

to cell proliferation or differentiation, sections of the bovine $\mathrm{CL}$ were immunostained with SMA and the proliferation marker, Ki-67. Ki-67-positive proliferative cells were abundant in the CL at the early-luteal stage (Fig. 6a) but decreased in number at the mid-luteal and lateluteal stages (Fig. 6b, c). Ki-67-positive cells scattered in 

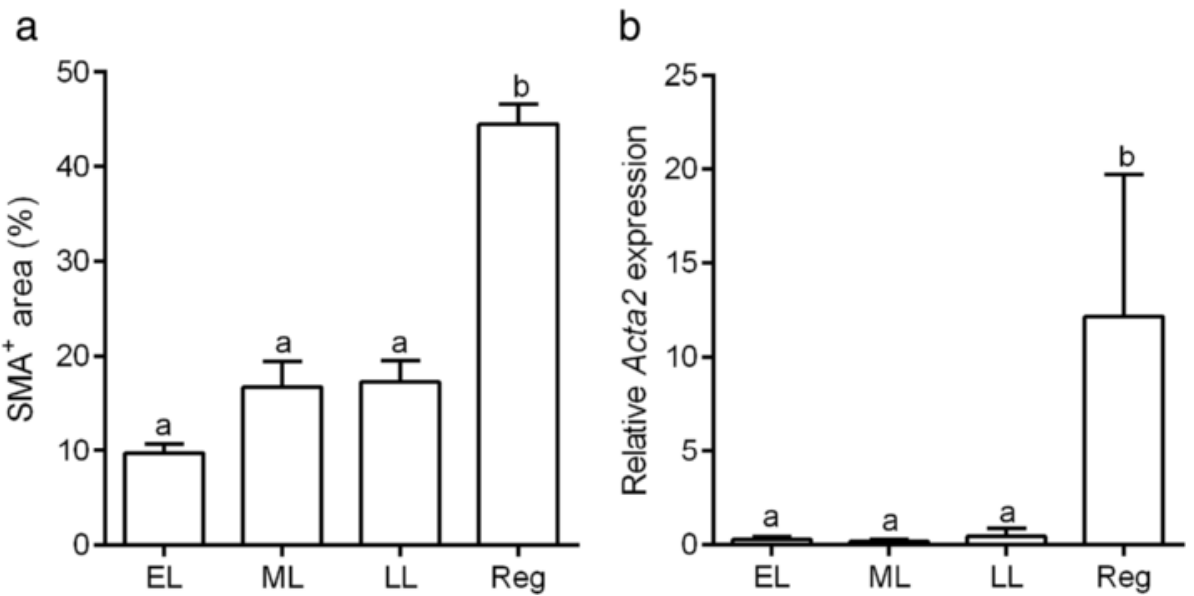

Fig. 4 Change in SMA-positive area and Acta2 mRNA expression in the $C L$ during luteal stages. The percentage of the area immunoreactive for SMA (a) and the mRNA expression of Acta2 significantly increase in the regressed $C L(\mathbf{b})$. Different letters show significant differences

the CL parenchyma and were not associated with SMAimmunoreactivity at the late-luteal stage (Fig. 6d-f). Most of Ki-67-positive proliferating cells seem to be luteal steroidogenic cells, endothelial cells, and immune cells as reported previously [23-26]. Thus, we concluded that resident cells - possibly fibroblasts- express SMA during luteal regression. Triple staining for SMA, vimentin, and desmin at the late-luteal and regressing stages showed that certain numbers of SMA-positive cells distributed throughout the CL parenchyma were immunoreactive for vimentin, suggesting that they were resident fibroblasts (Fig. $7 \mathrm{a}-\mathrm{d}$ ). On the other hand, the small arteries in the intraluteal connective tissues and arterioles in the CL parenchyma were also immunolabeled with all three markers (asterisks and arrows in Fig. 7a-d). Immunoreactivity for desmin was restricted to the tunica media, whereas that for SMA and vimentin was detected in the desmin-positive tunica media and in cells loosely surrounding the arteries (asterisks in 7E$\mathrm{H})$. During the early regressing stage, in which luteal steroidogenic cells remained between the crooked vessels, SMA and desmin co-localized in the walls of the arteries and arterioles consisting of epithelioid cells (asterisks and arrows in Fig. 7i-1), while the vimentin immunoreaction was found in the walls of arteries, but was slightly more abundant outside vessels (Fig. 7j). In the fully regressed $\mathrm{CL}$, the arterial wall became thicker and strongly expressed SMA and desmin, whereas immunoreactivity for vimentin was restricted more to the outside of these vessels (Fig. $7 \mathrm{~m}-\mathrm{p}$ ). These results suggest that a certain population of vimentin-positive fibroblasts contain SMA, and transform into myofibroblasts that strongly express desmin during luteal regression, and accumulate around arteries to form AVA-like vessels.

\section{PGF-induced TGF $\beta 1$ may contribute to myofibroblast transformation}

Since PGF is a major luteolysin in cows, it may play a role in the transformation of fibroblasts to myofibroblasts during luteolysis and in the construction of AVA-like vessels. Therefore, we examined change in the number of SMApositive cells and expression of Acta 2 mRNA in the CL collected 2-24 h after an injection of PGF. The staining pattern of SMA was similar to that in the CL during the mid-luteal stage, and the area positive for SMA in the CL and mRNA expression of Acta2 were not affected by the injection of PGF (Fig. 8a, b). On the other hand, PGF significantly enhanced the expression of transforming growth factor $\beta 1$ ( $T g f b 1)$, which is known to be essential for the transformation of myofibroblasts [27] (Fig. 8c). The expression of $T g f b 1$ was significantly increased during the late-luteal phase $(P \leq 0.01)$, and remained at a high level in the regressed stage (Fig. $8 \mathrm{~d}$ ), suggesting its contribution to luteolysis.

\section{Discussion}

This study revealed the detailed morphology of AVAlike vessels appearing in the regressed bovine CL and how they are constructed during luteolysis. The regressed CL of cows contained abundant atypical arteries with thick walls of epithelioid cells that were strongly immunoreactive for SMA. These SMA-positive cells forming the walls of AVA-like vessels are myofibroblasts transformed from resident fibroblasts during luteolysis: SMA-expressing fibroblastic cells with elongated cytoplasmic processes increased in number during the late-luteal stage and accumulated around the arteries to form AVA-like vessels. Luteolytic PGF is unlikely to be a direct cause of this phenomenon, but 

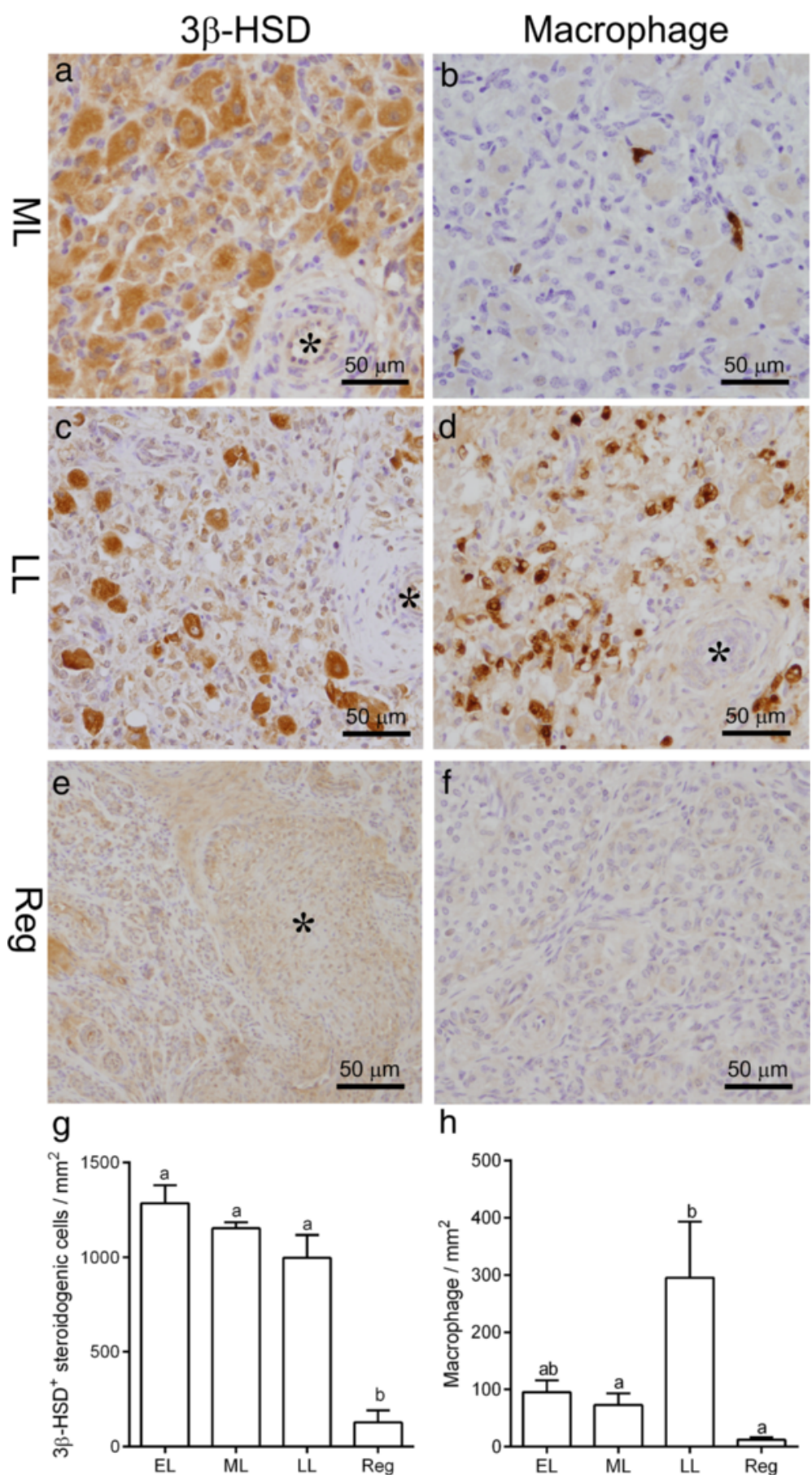

Fig. 5 Change in numbers of 3B-HSD-positive steroidogenic cells and macrophage in the CL during luteal stages. Abundant luteal steroidogenic cells immunoreactive for 3 3 -HSD while a few number of MAC387-positive macrophages are found in the $\mathrm{CL}$ at the mid-luteal (ML) stage (a, b). In the $\mathrm{CL}$ at the late-luteal (LL) stage, 3ß-HSD-positive cells scatters but abundant MAC387-positive cells are distributed (c, $\mathbf{d}$ ). In the regressed (Reg)

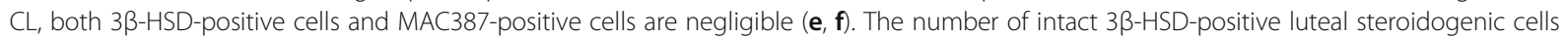
significantly decreases in the regressed $\mathrm{CL}(\mathbf{g})$ while MAC387-positive macrophages increase in the $\mathrm{CL}$ at the LL stage (h)

indirectly regulate the transformation of fibroblasts into myofibroblasts by enhancing the expression of TGF $\beta 1$, a potent regulator for myofibroblast transformation.
It is well known that the CL development is associated with angiogenesis and angiogenic factors such as vascular endothelial growth factor A and fibroblast growth 


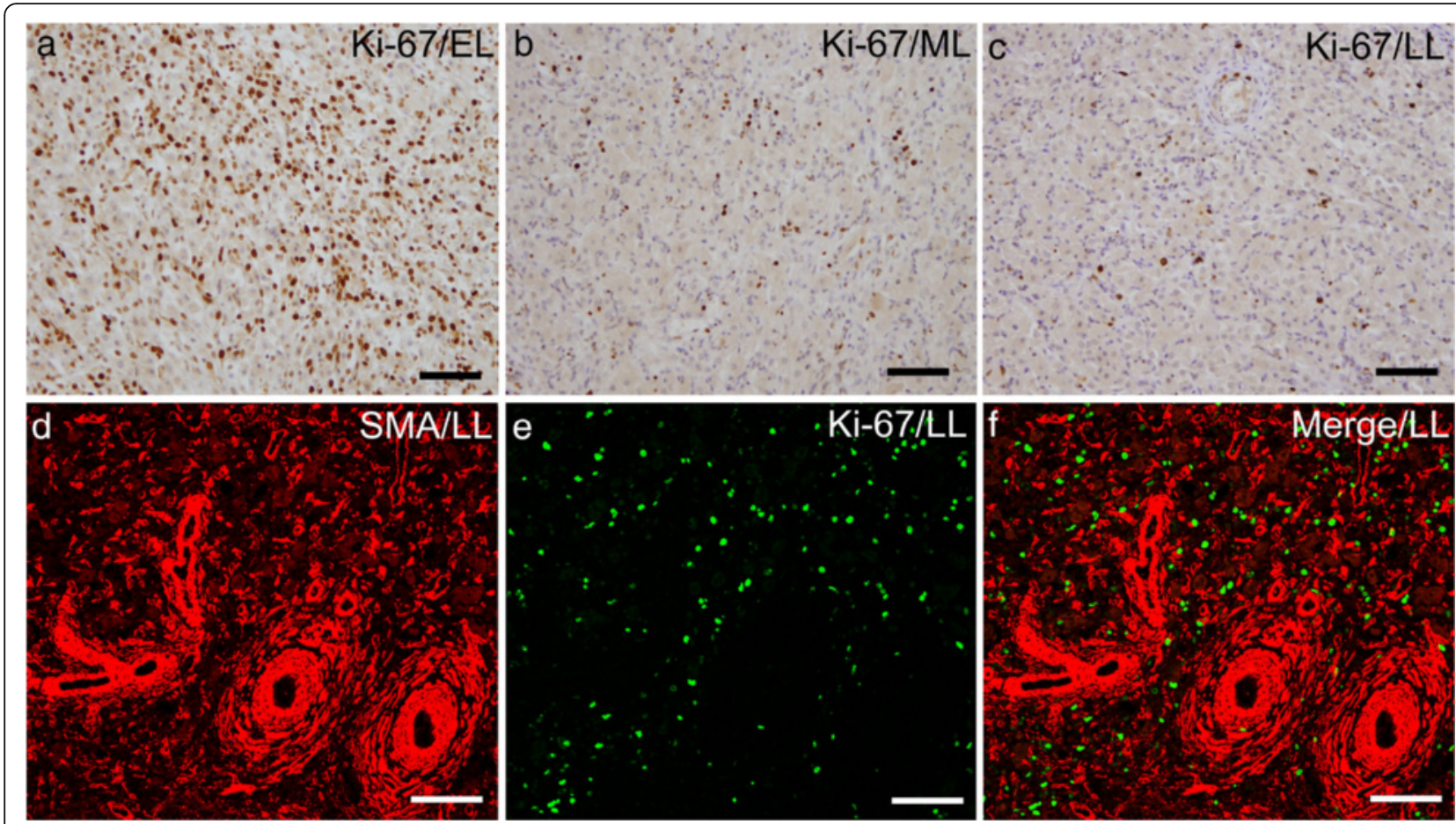

Fig. 6 Dual immunostaining for SMA and a proliferation marker, Ki-67. Ki-67-positive proliferating cells are abundant in the CL at the early-luteal (EL) stage (a) but decreases during the mid-luteal $(\mathrm{ML})$ and late-luteal $(\mathrm{LL})$ stages $(\mathbf{b}$, c). Most of SMA-positive cells (red) are not immunoreactive for Ki-67 (green) $(\mathbf{d}-\mathbf{f})$. Bars $=100 \mu \mathrm{m}$

factor 2 are involved in this process [28]. Endothelial cells proliferate in the developing $\mathrm{CL}$ and a fine network of capillary vessels is established in the CL at the midluteal stages accompanied by an increased serum progesterone level [28-30]. During luteal regression, apoptosis of luteal cells as well as endothelial cells occur and the number of capillary vessels decreases [31, 32], suggesting a dynamic vascular remodeling is involved in luteolytic process. We confirmed an existence of apoptotic cells in some CL at the late-luteal and early regressed stage, and certain numbers of apoptotic cells were endothelial cells (data not shown). However, capillaries were more visible when pericytes were immunostained for SMA in the CL at the late-luteal stage. We still do not know the role of SMA-positive pericytes in the regulation of luteolysis. On the other hand, some researchers noted an appearance of non-capillary vessels with thickened wall in the regressing $\mathrm{CL}$ of various animals including cows $[15,23,33]$, that show similar morphology to AVA-like vessels observed in this study.

The appearance of AVA-like vessels in the regressed bovine $\mathrm{CL}$ was previously reported by Höfliger [16]; in stages more than 25 days after ovulation, the CL consisted of crooked arteries with the characteristics of AVA. Bauer et al. [33] also noted an increased number of non-capillary vessels with thickened vessel walls in the bovine CL.
Hirschberg et al. [34] more recently reported the existence of AVA-like arteries with thickened medial layers showing SMA immunoreactivity during the later luteal stage in cows; however, they reported that "the source of this abundance of vascular smooth muscle-like cells is presently not clear". We revealed here that SMA-positive fibroblastic cells increased in number in the CL during the late-luteal stage, and accumulated around the arteries distributed in the periphery of the $\mathrm{CL}$ and intraluteal connective tissue. It is important to note that a certain population of SMA-immunoreactive cells was positive for vimentin in the $\mathrm{CL}$ during the late-luteal stage and proliferation marker, Ki-67, was not associated with an increase of SMA immunoreaction, suggesting that they are resident fibroblasts lying between luteal steroidogenic cells. As luteolysis progressed, the immunoreaction for SMA was restricted to the vascular epithelioid cells with a strong immunoreaction for desmin, a smooth muscle cellspecific intermediate filament. The arterial walls at this stage became thicker and the lumen became narrower, indicating a contractive condition. It is reasonable to assume that the origin of SMA-positive epithelioid cells in AVAlike vessels is myofibroblasts transformed from resident fibroblasts in the CL parenchyma. The AVA-like vessels appearing in association with luteolysis may assist luteolysis by decreasing luteal blood flow in cows. 


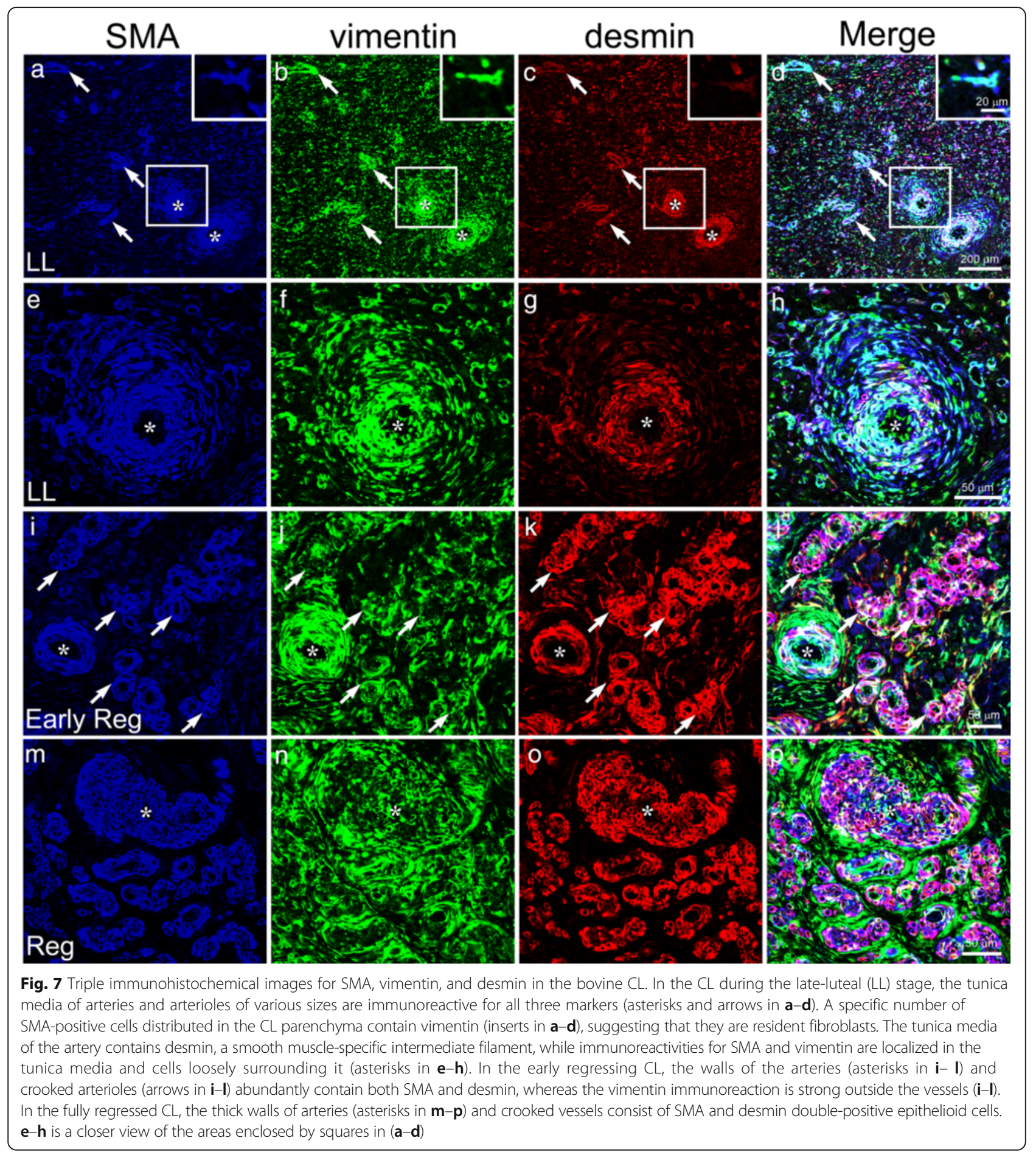

Ovarian blood flow is known to decrease during luteolysis $[4,12]$. Miyamoto et al. [3] clearly demonstrated this change in blood flow during spontaneous and PGFinduced luteolysis in cows. According to their findings, the concentrations of plasma PGF metabolites, indicating the production of uterine PGF, significantly increased 17 days after ovulation, and luteal blood flow concomitantly increased. They also showed that an intramuscular injection of PGF significantly decreased luteal blood flow after $8 \mathrm{~h}$, although a temporal increase of luteal blood flow was observed after $1 \mathrm{~h}$. In the spontaneously regressing CL, luteal blood flow decreases two days after a peak in plasma PGF metabolite concentrations [3]. The accumulation of SMA-positive myofibroblasts around the arteries in the 

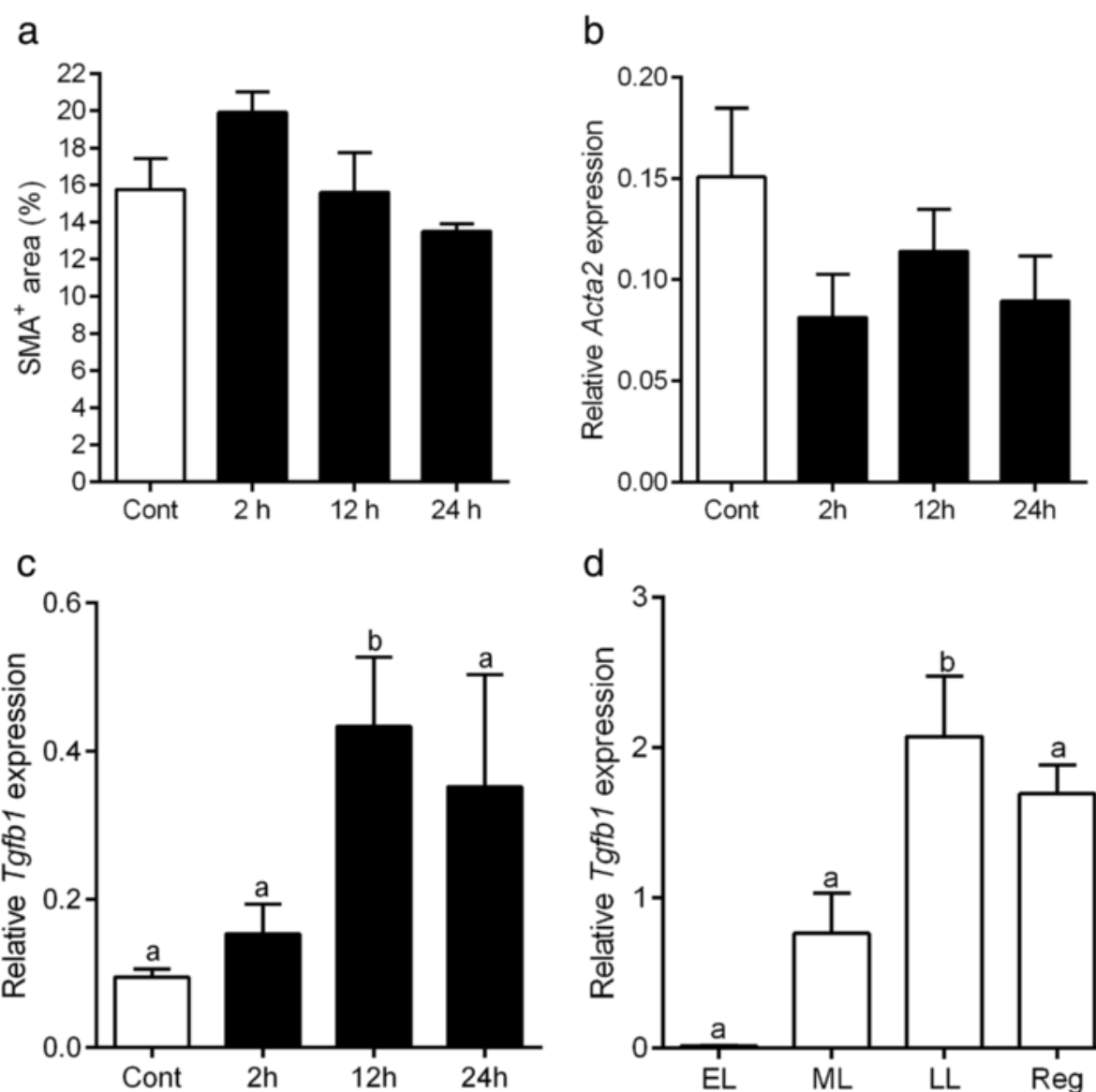

d

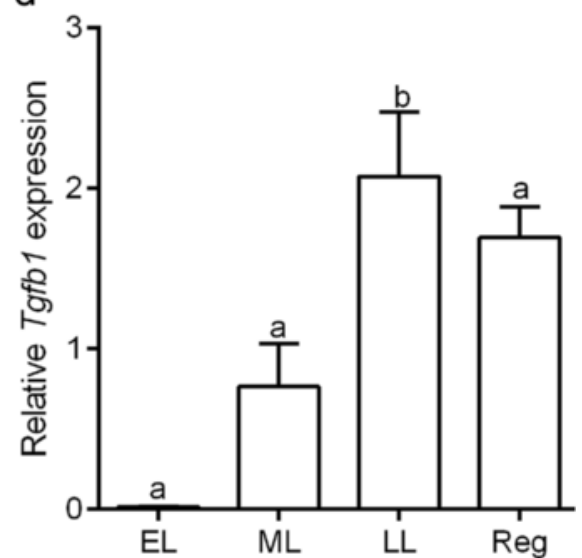

Fig. 8 Effect of PGF on the expression of SMA and TGF $\beta 1$. The percentage of the SMA-positive area remains unchanged in the CL 2-24 h after the injection of a luteolytic dose of PGF (a). The mRNA expression of Acta2 does not change by the PGF injection (b). On the other hand, the mRNA expression of Tgfb 1 - a known regulator of myofibroblast transformation — is significantly increased in the CL $12 \mathrm{~h}$ after the PGF injection (c) as well as in the $\mathrm{CL}$ during the late-luteal (LL) stage and regressed stage (d). Cont: the $\mathrm{CL}$ not treated with PGF. ML: mid-luteal, Reg: regressed CL. ${ }^{*} P<0.05,{ }^{* *} P<0.01$

CL during the late-luteal stage and following the establishment of AVA-like vessels in the regressed CL may be involved in decreasing blood flow during spontaneous luteolysis in cows. However, we failed to detect AVA-like vessels in the present PGF-induced regressing CL collected 2-24 h later. We consider that the AVA-like vessels are gradually established in the CL over the repeated estrous cycle because the CL with AVA-like vessels we classified into regressed $\mathrm{CL}$ contain the old regressed $\mathrm{CL}$ formed more than two cycle before and remained in the ovary. The formation of AVA-like vessels may be observed in the PGF-induced regressing CL collected more than $48 \mathrm{~h}$ after a PGF injection.

PGF is a major luteolysin in cows, but does not appear to directly regulate the transformation of fibroblasts to myofibroblasts because the present study failed to show the accumulation of SMA-positive cells or the upregulation of Acta2 mRNA expression with PGF-induced luteolysis. TGF $\beta 1$ is known to affect the transformation of fibroblasts into myofibroblasts. The results of the present study revealed that the administration of a luteolytic dose of PGF significantly enhanced the expression of $T g f b 1$ in the bovine CL. This is consistent with a previous study showing that PGF up-regulated the expression of TGF $\beta 1$ [35]. TGF $\beta 1$ has been suggested to activate fibroblasts in order to enhance the expression of contractile proteins such as SMA, vimentin, and desmin. Maroni and Davis [36] demonstrated that the treatment of luteal fibroblasts with TGF $\beta 1$ induced the expression of laminin, collagen type 1 , and matrix metalloproteinase 1 , suggesting that TGF $\beta 1$ stimulated by PGF is involved in fibrotic changes in the CL during luteolysis. TGF $\beta 1$ may influence steroidogenic actions in the bovine $\mathrm{CL}$ similar to other TGF $\beta$ superfamily members such as activin $A$ and bone morphogenetic proteins [37-39]. Nevertheless, TGF $\beta 1$ appears to contribute to the transformation of myofibroblasts during luteolysis in cows in order to establish AVA-like vessels. 


\section{Conclusions}

In conclusion, SMA-positive myofibroblasts accumulate around arteries to form AVA-like vessels in the regressing CL of cows. This morphological change in the vasculature appears to be regulated by PGF-induced TGF $\beta 1$, and may be involved in vascular occlusion and a reduction in blood flow during luteolysis in cows.

\section{Abbreviations}

AVA: Arteriovenous anastomosis; CL: Corpus luteum; PGF: Prostaglandin F $\mathrm{F}_{2 \mathrm{i}}$ qPCR: Quantitative PCR; SMA: a-smooth muscle actin; TEM: Transmission electron microscope; TGF $\beta 1$ : Transforming growth factor $\beta 1$

\section{Acknowledgments}

The authors appreciate to Prof. Seiji Katagiri, Associate Prof. Masahi Nagano, and the members of the Laboratory of Theriogenology, Graduate School of Veterinary Medicine, Hokkaido University, as well as Dr. Dariusz J. Skarzynski, Institute of Animal Reproduction and Food Research, Polish Academy of Science, for their kind help with collecting bovine $\mathrm{CL}$ tissues.

\section{Funding}

This work was supported by a Grant-in-Aid for Scientific Research (C) (General) (\#26460262) to JNK.

\section{Availability of data and materials}

Data supporting the findings of this manuscript has been included in the manuscript.

\section{Authors' contributions}

JNK conceived and designed the experiments. JNK and KM carried out the experiments, analyzed the data. $\mathrm{KH}$ and $\mathrm{KO}$ provided the PGF-treated bovine $\mathrm{CL}$ samples and technical support. JNK and TI wrote the manuscript and all authors read and approved the final manuscript.

\section{Competing interests}

The authors declare that they have no competing interests.

\section{Consent for publication}

Not applicable.

\section{Ethics approval and consent to participate} Not applicable.

\section{Author details}

${ }^{1}$ Laboratory of Histology and Cytology, Hokkaido University Graduate School of Medicine, Kita 15-Nishi 7, Kita-ku, Sapporo 060-8638, Japan. ${ }^{2}$ Laboratory of Reproductive Physiology, Graduate School of Environmental and Life Science, Okayama University, Tsushima Naka Kita-ku 1-1-1, Okayama 700-8530, Japan. ${ }^{3}$ Obihiro University of Agriculture and Veterinary Medicine, 2-11, Nishi, Inada-cho, Obihiro 080-8555, Japan.

Received: 14 August 2016 Accepted: 9 October 2016

Published online: 19 October 2016

\section{References}

1. Niswender GD, Juengel $J$, Silva PJ, Rollyson MK, Mclntush EW. Mechanisms controlling the function and life span of the corpus luteum. Physiol Rev. 2000:80:1-29.

2. McCracken JA, Custer EE, Lamsa JC. Luteolysis: a neuroendocrine-mediated event. Physiol Rev. 1999;79:263-323.

3. Miyamoto A, Shirasuna K, Wijayaqunawardane MP, Watanabe S, Hayashi M, Yamamoto D, Matsui M, Acosta TJ. Blood flow: a key regulatory component of corpus luteum function in the cow. Domest Anim Endocrinol. 2005;29: 329-39.

4. Wise TH, Caton D, Thatcher WW, Barron DH, Fields MJ. Ovarian function during the estrous cycle of the cow: ovarian blood flow and progesterone release rate. J Anim Sci. 1982;55:627-37.
5. Van Voorhis BJ, Dunn MS, Snyder GD, Weiner CP. Nitric oxide: an autocrine regulator of human granulosa-luteal cell steroidogenesis. Endocrinology. 1994;135:1799-806.

6. Olson LM, Jones-Burton CM, Jablonka-Shariff A. Nitric oxide decreases estradiol synthesis of rat luteinized ovarian cells: possible role for nitric oxide in functional luteal regression. Endocrinology. 1996;137:3531-9.

7. Gobbetti A, Boiti C, Canali C, Zerani M. Nitric oxide synthase acutely regulates progesterone production by in vitro cultured rabbit corpora lutea. Endocrinol. 1999;160:275-83.

8. Penny LA, Armstrong D, Bramley TA, Webb R, Collins RA, Watson ED. Immune cells and cytokine production in the bovine corpus luteum throughout the oestrous cycle and after induced luteolysis. J Reprod Fertil. 1999:115:87-96.

9. Skarzynski DJ, Kobayashi S, Okuda K. Influence of nitric oxide and noradrenaline on prostaglandin F2a-induced oxytocin secretion and intracellular calcium mobilization in cultured bovine luteal cells. Biol Reprod. 2000;63:1000-5.

10. Kobayashi S, Acosta TJ, Ozawa T, Hayashi K, Berisha B, Ohtani M, Schams D, Miyamoto A. Intraluteal release of angiotensin II and progesterone in vivo during corpora lutea development in the cow: effect of vasoactive peptides. Biol Reprod. 2002;66:174-9.

11. Shirasuna K, Asaoka H, Acosta TJ, Wijayaqunawardane MP, Matsui M, Ohtani M, Miyamoto A. Endothelin-1 within the corpus luteum during spontaneous luteolysis in the cow: local interaction with prostaglandin F2a and angiotensin II. J Cardiovasc Pharmacol. 2004;44 Suppl 1:S252-5.

12. Pharriss BB, Cornette JC, Gutknecht GD. Vascular control of luteal steroidogenesis. J Reprod Fertil Suppl. 1970;10:97-103.

13. Nishimura R, Komiyama J, Tasaki Y, Acosta TJ, Okuda K. Hypoxia promotes luteal cell death in bovine corpus luteum. Biol Reprod. 2008;78:529-36.

14. Sawyer HR, Niswender KD, Braden TD, Niswender GD. Nuclear changes in ovine luteal cells in response to PGF2 alpha. Domest Anim Endocrinol. 1990; 7:229-37

15. Hojo T, Al-Ziabi MO, Skarzynski DJ, Acosta TJ, Okuda K. Changes in the vasculature of bovine corpus luteum during the estrous cycle and prostaglandin F2alpha-induced luteolysis. J Reprod Dev. 2009:55:512-7.

16. Höflinger $\mathrm{H}$. Das Ovar des Rindes in den verschiedenen Lebensperioden unter besonderer Berücksichtigung seiner funktionellen Feinstruktur (The functional fine structure of the bovine ovary in its different cyclic conditions). Acta Anat. 1947;3 suppl 5:1-196.

17. Rondell PA, Keitzer WF, Bohr DF. Distribution of flow through capillaries and arteriovenous anastomoses in the rabbit ear. Am J Physiol. 1955; 183:523-8.

18. Gorgas K, Böck P, Tischendorf F, Curri SB. The fine structure of human digital arterio-venous anastomoses (Hoyer-Grosser's organs). Anat Embryol (Berl). 1977;150:269-89.

19. Böck P, Gorgas K. Morphology and histochemistry of helicine arteries in the corpora cavernosa penis of mice. Arch Histol Jpn. 1977;40:265-81.

20. Li Z, Koman LA, Rosencrance E, Smith BP, Smith TL. Endogenous nitric oxide influences arteriovenous anastomosis adrenergic tone in the conscious rabbit ear. J Cardiovasc Phamacol. 1998:32:349-56.

21. Miyamoto Y, Skarzynski DJ, Okuda K. Is tumor necrosis factor alpha a trigger for the initiation of endometrial prostaglandin F2alpha release at luteolysis in cattle? Biol Reprod. 2000;62:1109-15.

22. Shirasuna K, Nitta A, Sineenard J, Shimizu J, Shimizu T, Bollwein H, Miyamoto A. Vascular and immune regulation of corpus luteum development, maintenance, and regression in the cow. Domest Anim Endocrinol. 2012;43:198-211.

23. Young FM, Rodger FE, Illingworth PJ, Fraser HM. Cell proliferation and vascular morphology in the marmoset corpus luteum. Hum Reprod. 2000; 15:557-66.

24. Yoshioka S, Abe H, Sakumoto R, Okuda K. Poliferation of luteal steroidogenic cells in cattle. PLoS One. 2013:8:e84186.

25. Jablonka-Shariff A, Grazul-Bilska AT, Redmer DA, Reynolds LP. Growth and cellular proliferation of ovine corpora lutea throughout the estrous cycle. Endocrinology. 1993;133:1871-9.

26. Zheng J, Fricke PM, Reynold LP, Redmer DA. Evaluation of growth, cell proliferation, and cell death in bovine corpora lutea throughout the estrous cycle. Biol Reprod. 1994;51:623-32.

27. Desmoulière A, Geinoz A, Gabbiani F, Gabbiani G. Transforming growth factor-beta 1 induces alpha-smooth muscle actin expression in granulation 
tissue myofibroblasts and in quiescent and growing cultured fibroblasts. J Cell Biol. 1993;122:103-11.

28. Woad KJ, Robinson RS. Luteal angiogenesis and its control. Theriogenology. 2016;86:221-8.

29. Redmer DA, Doraiswamy V, Borthnem BJ, Fisher K, Jablonka-Shariff A, Grazul-Bilska AT, Reynolds LP. Evidence for a role of capillary pericytes in vascular growth of the developing ovine corpus luteum. Biol Reprod. 2001; 65:879-89.

30. Hünigen H, Bisplinghoff P, Plendl J, Bahramsoltani M. Vascular dynamics in relation to immunolocalisation of VEGF-A, VEGFR-2 and Ang-2 in the bovine corpus luteum. Acta Histochem. 2008;110:462-72.

31. O'Shea JD, Nightingale MG, Chamley WA. Changes in small blood vessels during cyclical luteal regression in sheep. Biol Reprod. 1977;17:162-77.

32. Azmi TI, O'Shea JD. Mechanism of deletion of endothelial cells during regression of the corpus luteum. Lab Invest. 1984:51:206-17.

33. Bauer M, Schilling N, Spanel-Borowski K. Development and regression of non-capillary vessels in the bovine corpus luteum. Cell Tissue Res. 2003;311: 199-205.

34. Hirschberg RM, Plendl J, Kaessmeyer S. Alpha smooth muscle actin in the cycling ovary - an immunohistochemical study. Clin Hemorheol Microcirc. 2012;50:113-29.

35. Hou X, Arvisais EW, Jiang C, Chen DB, Roy SK, Pate JL, Hansen TR, Rueda BR, Davis JS. Prostaglandin F2alpha stimulates the expression and secretion of transforming growth factor B1 via induction of the early growth response 1 gene (EGR1) in the bovine corpus luteum. Mol Endocrinol. 2008;22:403-14.

36. Maroni D, Davis JS. Transforming growth factor Beta 1 stimulates profibrotic activities of luteal fibroblasts in cows. Biol Reprod. 2012;87:127.

37. Myers M, Gay E, McNeilly AS, Fraser HM, Duncan WC. In vitro evidence suggests activing-A may promote tissue remodeling associated with human luteolysis. Endocrinology. 2007;148:3730-9.

38. Myers $\mathrm{M}$, van den Driesche $\mathrm{S}$, McNeilly AS, Duncan WC. Activin A reduces luteinisazion of human luteinized granulosa cells and has opposing effects to human chorionic gonadotropin in vitro. J Endocrinol. 2008;199:201-12.

39. Nio-Kobayashi J, Trendell J, Giakoumelou S, Boswell L, Nicol L, Kudo M, Sakuragi N, Iwanaga T, Duncan WC. Bone morphogenetic proteins are mediators of luteolysis in the human corpus luteum. Endocrinology. 2015; 156:1494-503.

\section{Submit your next manuscript to BioMed Central and we will help you at every step:}

- We accept pre-submission inquiries

- Our selector tool helps you to find the most relevant journal

- We provide round the clock customer support

- Convenient online submission

- Thorough peer review

- Inclusion in PubMed and all major indexing services

- Maximum visibility for your research

Submit your manuscript at www.biomedcentral.com/submit

) Biomed Central 